\title{
Investigating university academics behavioural intention in the adoption of e-learning in a time of COVID-19
}

\begin{tabular}{|c|c|}
\hline \multicolumn{2}{|c|}{$\begin{array}{l}\text { Author: } \\
\text { Joseph N. Jere }{ }^{1}\end{array}$} \\
\hline \multicolumn{2}{|c|}{$\begin{array}{l}\text { Affiliation: } \\
{ }^{1} \text { Discipline of Information } \\
\text { Systems and Technology, } \\
\text { College of Law and } \\
\text { Management Studies, } \\
\text { KwaZulu-Natal University, } \\
\text { Pietermaritzburg, } \\
\text { South Africa }\end{array}$} \\
\hline \multicolumn{2}{|c|}{$\begin{array}{l}\text { Corresponding author: } \\
\text { Joseph Jere, } \\
\text { jeren@ukzn.ac.za }\end{array}$} \\
\hline \multicolumn{2}{|c|}{$\begin{array}{l}\text { Dates: } \\
\text { Received: } 01 \text { July } 2020 \\
\text { Accepted: } 02 \text { Oct. } 2020 \\
\text { Published: } 21 \text { Dec. } 2020\end{array}$} \\
\hline \multicolumn{2}{|c|}{$\begin{array}{l}\text { How to cite this article: } \\
\text { Jere, J.N., 2020, 'Investigating } \\
\text { university academics } \\
\text { behavioural intention in } \\
\text { the adoption of e-learning } \\
\text { in a time of COVID-19', } \\
\text { South African Journal of } \\
\text { Information Management } \\
\text { 22(1), a1280. https://doi.org/ } \\
\text { 10.4102/sajim.v22i1.1280 }\end{array}$} \\
\hline \multicolumn{2}{|c|}{$\begin{array}{l}\text { Copyright: } \\
\text { (c) 2020. The Authors. } \\
\text { Licensee: AOSIS. This work } \\
\text { is licensed under the } \\
\text { Creative Commons } \\
\text { Attribution License. }\end{array}$} \\
\hline \multicolumn{2}{|l|}{ Read online: } \\
\hline 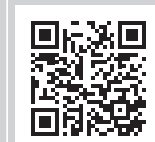 & $\begin{array}{l}\text { Scan this QR } \\
\text { code with your } \\
\text { smart phone or } \\
\text { mobile device } \\
\text { to read online. }\end{array}$ \\
\hline
\end{tabular}

Background: The coronavirus disease of 2019 (COVID-19) has extensively impacted various sectors globally, including higher education. The indefinite closure of Universities has necessitated the need to introduce alternative teaching and learning methods and tools. E-learning, a disruptive innovation, has provided an opportunity to allow for continuity of teaching and learning in Universities during these closures.

Objectives: The study adopts Teo's model as the analytical tool to investigate factors that influence University lecturers to adopt e-learning platforms in South Africa.

Method: The study followed a quantitative research approach with stratified sampling as a data collection approach using a sample size of 132 respondents. Structural Equation Modelling (SEM) was adopted to deduce factors that influence the Behavioural Intention to Use (BIU) to adopt e-learning, as well as to test the Model fit of Teo's model in the South African context.

Results: The study revealed that the lecturer's attitude towards the use (ATU) of e-learning is the most influential construct towards lecturers' BIU e-learning platforms. The empirical evidence also revealed that Teo's model is a reasonable fit to the data to understand the adoption of e-learning by lecturers in South African universities.

Conclusion: The empirical evidence from this study supports the viewpoint that in order for lecturers to successfully adopt e-learning platforms, their attitude towards the use of these platforms seems to be a critical factor. In order to understand lecturer's adoption of e-learning platforms successfully, Teo's model is a reasonably good framework to use.

Keywords: e-learning; structural equation modelling; Information Communication Technology; Behavioural Intention to Use; Fourth Industrial Revolution; Teo's model.

\section{Introduction}

The global higher education sector has been extensively impacted by the coronavirus disease of 2019 (COVID-19) pandemic, which has led to the unplanned closure of Universities (Flaxman et al. 2020; Hale et al. 2020). South Africa has been no exception to this impact, with the minister of higher education Dr Blade Nzimande announcing the early closure of Universities on 18 March 2020 (Nzimande 2020), which was necessitated to protect the general student population from the pandemic. The indefinite closure combined with the desire to save the academic year necessitated the need for exploring the development of alternative modes of teaching and learning.

The introduction of Information and Communication Technologies (ICTs) in higher education has been a disruptive innovation changing how teaching and learning are delivered and perceived. As a result of the growth in the development of ICT, the higher education sector landscape is continuously changing as well (Priya, Elayampalayam \& Nadu 2018; Singh 2017). The changes have brought about a new model for education known as e-learning (Al-Samarraie et al. 2018; Ting, Smith \& Gomez 2018). Over the years, students entering institutions of higher learning have become more and more tech-savvy and spend large amounts of time online be it for social purposes or educative (Azhar, Kim \& Salman 2018; Mládková 2017). The COVID-19 pandemic, the mainstreaming of technology in education and the desire to meet students in 'their spaces' to maximise educational processes, has led Universities around the world to move towards adopting this new model of education. The implementation of e-learning technologies in higher education has caused a vivid transformation in teaching and learning pedagogies (Baltodano \& Gomez-Zermeno 2017).

There are two types of institutions of higher learning, full contact universities where teaching and learning take place on a face-to-face basis between lecturers and students, and then there 
are also distance education institutions where teaching and learning take place remotely. E-learning is a disruptive innovation in full contact universities (Flavin \& Quintero 2018), in the sense that it is a new paradigm of education delivery that is bringing change to the way education has traditionally been delivered to students. Traditional learning is learning delivered at full contact universities in an appropriate environment known as a classroom (Ansong et al. 2016). The introduction of e-learning is bringing about new teaching techniques that are disrupting the traditional ones.

Key players in the implementation of e-learning are lecturers and students. The role of lecturers in the successful implementation of an e-learning system is critical as their role is similar to that identified by Rogers (2010) of opinion leaders. Therefore, the adoption of e-learning technologies by lecturers tends to have a direct influence on students' adoption of these technologies (Tarhini et al. 2017). Lecturer's knowledge, understanding and adoption of these technologies are vital to the successful implementation of e-learning (Xhaferi \& Bahiti 2018). A number of challenges exist with regard to lecturers' adoption of e-learning (Opoku, Pobee \& Okyireh 2020).

In developed countries such as the United States and the United Kingdom, the use of ICTs in education is at present changing educational pedagogies in institutions of higher learning. Institutional and socio-economic factors are the main driving forces behind e-learning acceptance (Freeman, Antwi-Boampong \& Agyemang 2019). Developing countries such as South Africa and India are now using e-learning to leapfrog into the knowledge society, allowing these countries to participate in the global society (Patel, Kadyamatimba \& Madzvamuse 2018; Pattanayak et al. 2019). South Africa has got over 100 institutions of higher learning that are offering various diploma and degree programmes (Parent24 2017), although only a handful offer online courses providing an insight towards e-learning penetration in institutions of higher learning. E-learning technologies are also used within institutions of higher learning to provide additional scaffolding for contact courses. Conventional e-learning technologies used by full contact higher education institutions usually consist of Learning Management Systems (LMSs), such as Moodle and Blackboard. The University under study is a full contact university with one of the highest student populations and stands amongst the top 10 highest ranking institutions in South Africa. The University of KwaZuluNatal (UKZN) is amongst several institutions of higher learning, which has embraced ICTs; it is also amongst several institutions of higher learning, which has embraced ICTs in education and has shifted its focus to remote online learning because of the COVID-19 pandemic as a strategy to allow for the continuity of teaching and learning. A review of the 26 Universities in South Africa (DHET 2020) reveals that nearly all of the Universities have implemented a form of e-learning, mainly making use of LMSs. As universities are now shifting to e-learning as the mode of implementing teaching and learning, it becomes essential to investigate lecturer's behavioural intention to adopt these e-learning technologies.
A number of studies on ICTs have examined descriptive models in the adoption of technologies that assist in predicting adoption, as well as in usage behaviour (Dwivedi et al. 2019; El-Masri \& Tarhini 2017). Timothy Teo suggests a model of e-learning adoption by lecturers. This model developed by Teo (2011) consolidates constructs from the theories mentioned above in explaining the adoption process of technology. This study seeks to investigate the factors that influence Behavioural Intention to Use (BIU) to adopt e-learning by lecturers using Teo's model in the South African context and to test whether Teo's model applies in this context. This study attempts to provide a more holistic understanding of e-learning adoption at full contact institutions of higher learning.

\section{Research objectives}

- To investigate factors that influence BIU to adopt e-learning by lecturers.

- To test whether Teo's model applies to the South African context.

\section{Literature review}

Traditional learning is the most common method of delivering education to students (Ingadottir et al. 2020). It is characterised by face-to-face interactions of students and lecturers in a common learning space called a classroom. Traditional learning has its advantages over e-learning (Table 1). However, e-learning is promising to be the future of education delivery because of disruptive innovations such as the Internet and the outbreak of pandemics like COVID-19, which emphasises social distancing. Table 1 outlines the advantages and disadvantages of e-learning as was adapted from Zhang et al. (2004). The study (Zhang et al. 2004) pointed out that e-learning was advantageous than traditional learning, even though it had some issues to be considered.

\section{E-learning concept}

Electronically supported learning, commonly known as e-learning, is conducted using the Internet (Vaona et al. 2018).

TABLE 1: Traditional learning versus e-learning.

\begin{tabular}{|c|c|c|}
\hline Variable & Traditional classroom learning & E-learning \\
\hline Advantages & $\begin{array}{l}\text { - Immediate feedback } \\
\text { - Being familiar to both } \\
\text { instructors and students } \\
\text { - Motivating students } \\
\text { - Cultivation of a social } \\
\text { community }\end{array}$ & $\begin{array}{l}\text { - Learner-centred and self-paced } \\
\text { - Time and location flexibility } \\
\text { - Cost-effective for students } \\
\text { - Potentially available to global } \\
\text { audience } \\
\text { - Unlimited access to knowledge } \\
\text { - Archival capability for } \\
\text { knowledge reuse and sharing }\end{array}$ \\
\hline Disadvantages & $\begin{array}{l}\text { - Instructor-centred } \\
\text { - Time and location constraints } \\
\text { - More expensive to deliver }\end{array}$ & $\begin{array}{l}\text { - Lack of immediate feedback in } \\
\text { asynchronous e-learning } \\
\text { - Increased preparation time for } \\
\text { the instructor } \\
\text { - Not comfortable to some people } \\
\text { - Potentially more frustration, } \\
\text { anxiety, and confusion }\end{array}$ \\
\hline
\end{tabular}

Source: Zhang, D., Zhao, J.L., Zhou, L. \& Nunamaker, Jr. J.F., 2004, 'Can e-learning replace classroom learning?', Communications of the ACM 47(5), 75-79. https://doi.org/10.1145/ 986213.986216 
E-learning is a phenomenon that facilitates access to educational materials, boosting learning excellence, and advancing teaching techniques and practices through the use of ICTs (Güllü et al. 2016).

Algahtani (2011) classifies e-learning into two categories, namely, computer-based and internet-based. Computerbased e-learning is where computers are used to retrieve and store educational information or are used to provide communicating software to support learning that does not involve use of the Internet in class or for the individual learning (Wall et al. 2017). Internet-based learning is an extension of computer-based learning; it is divided into a blended mode (Kristanto 2017) and fully online learning (Davey, Elliott \& Bora 2019). The blended model offers a combination of both traditional and online learning, whilst fully online is an entirely online experience.

\section{Adoption of e-learning platforms}

The e-learning adoption process has exponentially increased globally in full contact institutions of higher learning because of the outbreak of the COVID-19 pandemic. The growth in the use of the higher education sector seems to be increasing the adoption of e-learning in higher education institutions (Al-Samarraie et al. 2018). The student attrition from e-learning courses hinders e-learning adoption by lecturers (Burgess 2017). Al-Azawei, Parslow and Lundqvist (2016) identify some challenges to e-learning adoption as being a lack of student, technical and administrative support; lack of staff development; poor Internet connectivity and content not being localised to fit particular cultures.

Teo (2011) encourages the continuous upskilling of lecturers in order to be able to maximise the use of these technological innovations that are constantly evolving. The author identifies factors such as age, computer experience, years of teaching experience and gender as keeping key in successful adoption. Age plays a significant role in lecturers who lack computer skills, especially when receiving basic instructions (Morin, Fard \& Saadé 2019). The time needed to structure an e-learning programme is more than when preparing for traditional ones and tends to be a challenge (Al-Azawei et al. 2016).

Higher learning institutions need to plan, implement and then monitor technology adoption as they influence lecturers' behavioural intention to adopt e-learning (Teo 2011). Clarity on universities' e-learning policies helps lecturers to fully utilise it in supplementing their teaching strategies (Moakofhi et al. 2017).

\section{Factors affecting the adoption of e-learning platforms}

Behavioural Intention to Use ICT technologies are linked to successful adoption of e-learning (Chang, Hajiyev \& Su 2017; El-Masri \& Tarhini 2017). Behavioural Intention to use is how firm a person is eager to perform a behaviour or to adopt a technology (Teo 2011). The following factors have a direct or indirect influence on lecturers' BIU e-learning indicated by the reviewed literature.

\section{Perceived usefulness and perceived ease of use}

Perceived usefulness (PU) is the user's assumption that using a specific system will generally increase job performance, and perceived ease of use (PEU) is user's assumption that using a particular technology system is effortless as defined by Sugandini et al. (2018) and Teo (2011). Lecturers' PU and PEU affect the way they will behave towards the adoption of e-learning. The study carried out by Nikou and Economides (2017) revealed that BIU is significantly impacted by a systems usefulness and its ease of use. Teo (2011) in his study then specified that PU directly influences BIU and PEU, indirectly influences BIU through PU which is also in line with what is suggested by Davis (1989) in the Technology Acceptance Model (TAM) and Venkatesh et al. (2003) in the Unified Theory of Acceptance and Use of Technology (UTAUT).

\section{Subjective norms}

Subjective norms (SNs) are persons' view of what their peers or those they consider to be of important think of them should they engage or not engage in a particular behaviour (Oteng-Peprah, De Vries \& Acheampong 2020; Teo \& Lee 2010). In his study, Teo (2011) found that SNs had an insignificant influence on BIU on lecturers but had a significant influence on PU, which indicated that it had an indirect effect on BI. Subjective norms imply that lecturers perceive their behaviour to be influenced by the ones they view as important referents.

\section{Facilitating conditions}

Facilitating conditions (FCs) are the extent to which a user believes that there is the technical and organisational infrastructure to support the use of a system (Molina-Castillo, Lopez-Nicolas \& De Reuver 2020). Lecturer's perception of e-learning is affected by technical support, training on using e-learning and administrative support. There was no significant influence of FCs on BIU in the study carried out by Teo and Noyes (2014) using UTAUT. Teo (2011) elaborated that there was a significant direct influence of FC on BIU and also indirectly significantly influenced BIU through PEU because as lecturers get the technical support, they are said to perceive the technology easy to use.

\section{Attitude towards use}

Attitude Towards Use (ATU) is how a lecturer reacts to and is willing to use a technology (Teo \& Lee 2010). A study conducted by Teo (2011) showed that ATU has a direct influence on a person's BIU technology. In agreement with this, another study carried out by Mosa, Mahrin and Ibrrahim (2016) indicated that attitude plays a vital role in determining the overall readiness of e-learning adoption. These studies indicate that ATU is a factor that affects the adoption of e-learning. 


\section{The three theories from which Teo's model formulates}

The need to know and appreciate users' adoption and usage behaviour have made researchers to use numerous models and theories that originate from psychology, such as TAM, UTATUT and Theory of Planned Behaviour (TPB).

\section{Technology acceptance model}

Technology Acceptance Model was developed by Davis (1989), which states that to determine user acceptance, one needs to look at critical constructs, which are PEU and PU. The TAM theory is also used to successfully explain user acceptance of disruptive technologies (Schmidthuber, Maresch \& Ginner 2020). The theory investigates the relations amongst PU, PEU, ATU and BIU technology (Figure 1). Perceived ease of use is suggested to have a direct influence on PU, and the two affect ATU. Attitude towards use affects BIU, which is also suggested to be directly and indirectly affected by PU and PEU (Teo 2011).

This model proposed by Davis (1989) suggests that users' behaviour can be explained by their PEU, PU and their attitude towards that technological innovation. The construct attitude has the most direct influence on the behavioural intention to adopt the innovation.

\section{Theory of planned behaviour}

Developed by Ajzen (1991), the TPB holds that a person's behavioural intention is the significant predictor of the behaviour; it also factors how much people are eager to execute a behaviour. Subjective norms, Attitude towards behaviour (ATU) and perceived behavioural control (Figure 2) are the determinants of BIU (Savari \& Gharechaee 2020). This theory was, however, an improvement of the Theory of Reasoned Action (TRA), which had two constructs, namely, attitude towards the behaviour and SNs. Hence, TPB added perceived behavioural control to give more explanatory power to TRA (Sultan et al. 2020).

The TPB consists of four constructs, which determine user behaviour as theorised by Ajzen (1991). In this theory behaviour is directly impacted by intention, whilst the intention is influenced by perceived behavioural control, SNs and attitude towards the behaviour.

\section{Unified theory of acceptance and use of technology}

The UTAUT was designed by Venkatesh et al. (2003), which meant to explain the acceptance and use of information system innovations. The model consists of four core constructs: technology usage intention, which include performance expectancy, effort expectance, FCs and social influence (Figure 3). These may be qualified by voluntariness to use technology, age, experience and gender.

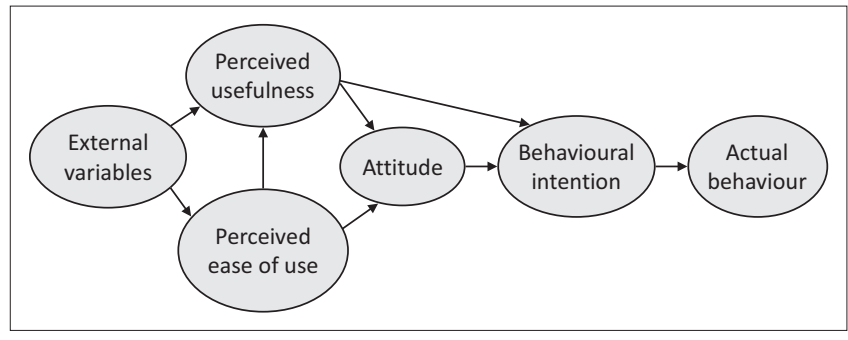

Source: Davis, F.D., 1989, 'Perceived usefulness, perceived ease of use, and user acceptance of information technology', MIS Quarterly 13(3), 319-340. https://doi.org/10.2307/249008 FIGURE 1: The relationships of the constructs of technology acceptance model.

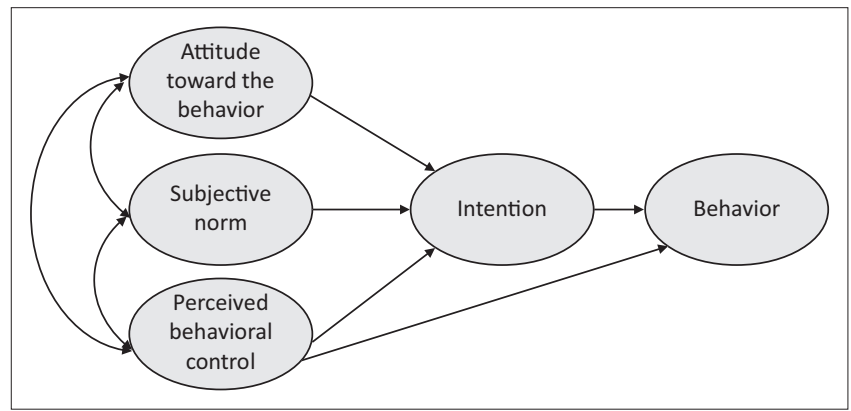

Source: Ajzen, I., 1991, 'The theory of planned behavior', Organizational Behaviour and Human Decision Processes 50(2), 179-211. https://doi.org/10.1016/0749-5978(91)90020-T FIGURE 2: The relationships of the determinants of the theory of planned behaviour.

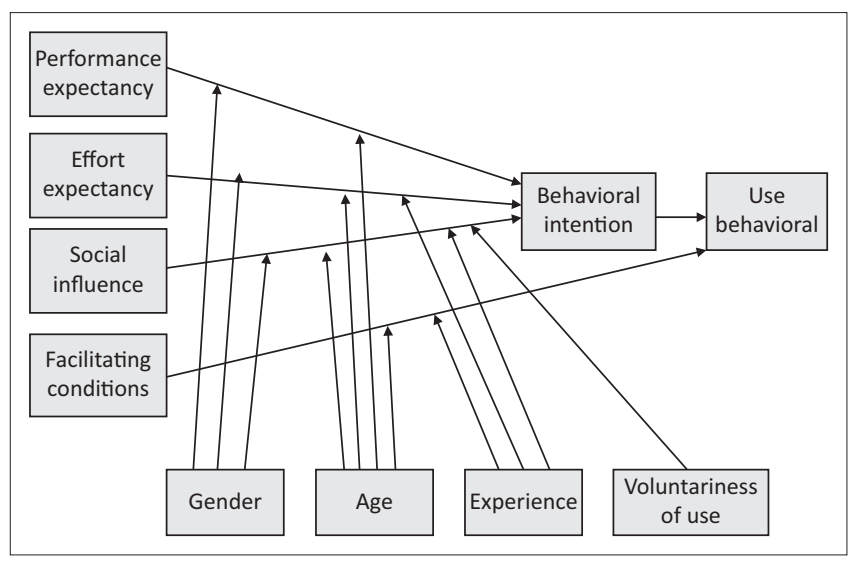

Source: Venkatesh, V., Morris, M., Davis, G. \& Davis, F.D., 2003, 'User acceptance of information technology: Toward a unified view', MIS Quarterly 27(3), 425-478. https://doi. org/10.2307/30036540

FIGURE 3: The relationships of the constructs of a unified theory of acceptance and use of technology.

The UTAUT model developed by Venkatesh et al. (2003) consists of four core constructs (performance expectancy, effort expectancy, FCs and social influence). All except FCs directly influence user behavioural intention, which also determines user behaviour. Facilitating conditions and behavioural intention both directly impact user behaviour.

\section{Teo's model}

Teo's model used in this research takes into account six constructs from the above theories, which are as follows: PEU, PU, SNs, ATU, FCs and BIU (Figure 4). In as much as TPB is the base of the human behavioural study, there is also a need to look at other contributing factors that affect an individual's decisions on adoption of e-learning. 


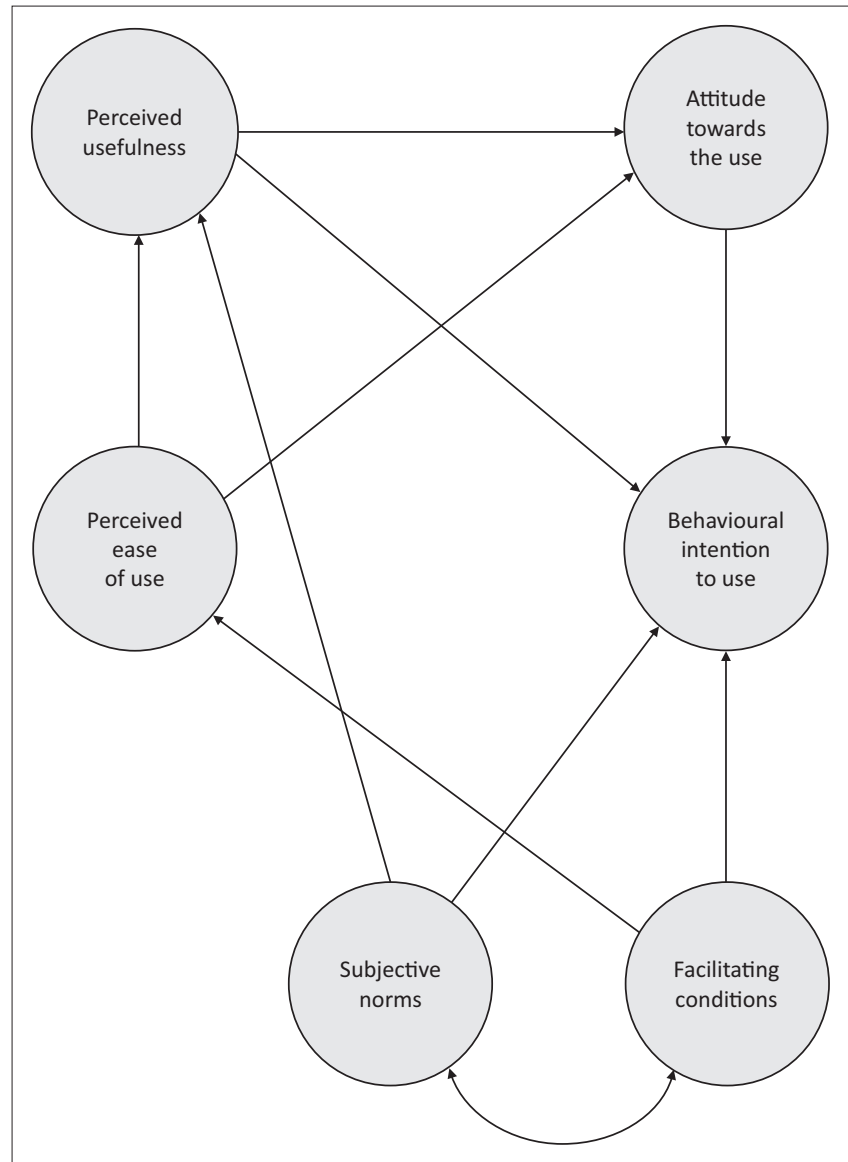

Source: Teo, T., 2011, 'Factors influencing teachers' intention to use technology: Mode development and test', Computers \& Education 57(4), 2432-2440. https://doi.org/10.1016/j. compedu.2011.06.008

FIGURE 4: The relationships amongst constructs.

This model explains the influences of a person's BIU to adopt a technology. Teo's model seems to provide a more holistic consideration of the factors identified in the literature, and therefore, seems to be a better suitable model to use in investigating the BIU e-learning platforms by lecturers.

Teo's model makes use of six constructs from the previously discussed adoption theories. The model consists of the following constructs: PEU, PU, SNs, ATU, FC and BIU. Out of the six, five are used to determine their influence on the sixth construct BIU.

\section{Research methodology}

For this study, the quantitative approach was more appropriate, as the study looked at the relationships amongst the constructs consolidated in the model to be applied. Statistical data were collected and analysed to give a more detailed description of the phenomenon (Mertler \& Reinhart 2016). The study was conducted in a South African University, the UKZN Pietermaritzburg (PMB) campus using a convenient sampling method. Data were collected using a closed-ended questionnaire, which included a consent form.

The target population of the study included all of the UKZN PMB campus colleges, which consisted of a total of
200 lecturers. The sample size of 132 was calculated, taking into consideration a confidence level of $95 \%$, a margin of error of $5 \%$ and a response distributor of 50 . In an attempt to make the sample more representative, the researcher divided the sample to consist of an even number of lecturers from all three colleges. Therefore, the sample of this study consisted of 44 lecturers from the College of Law and Management Studies, 44 lecturers from the College of Humanities and 44 lecturers from the College of Agriculture Engineering and Science.

The study aimed at investigating the factors that influence BIU to adopt e-learning by UKZN PMB campus lecturers and to test whether Timothy Teo's model is applicable in the South African context. A closed-ended research questionnaire was distributed to a target of 132 lecturers who participated in the study through the use of convenient sampling. The response rate was $100 \%$. The sampling instrument was divided into sections that measure the constructs suggested by Teo, which helped in obtaining the results that answered the research objectives. Questions under each construct had responses: strongly agree, agree, neutral, disagree and strongly disagree, the scores placed on each was $1,2,3,4,5$, respectively, as the instrument used a Likert scale. Cronbach's Alpha was conducted to ensure internal uniformity of items as a group as the questionnaire had Likert scale questions. The reliability of the scale chosen for the questionnaire was tested with an accepted index of reliability being 0.7 and upwards (Bujang, Omar \& Baharum 2018). Composite variables were created to conduct some of the tests. The normality test was also conducted to check the distribution of the data. Structural Equation Modelling (SEM) analysis, which served more as a confirmatory test rather than a predictive test, was adopted in this study. Structural equation modelling analysed the relationships between latent (unobserved) and observed variables (Byrne 2016). Structural equation modellings' ability to model random errors in the observed variables resulted in detailed measurements and allowed for the testing of the validity of the proposed model.

\section{Ethical consideration}

Ethical consideration was received from the University of KwaZulu-Natal Humanities and Social Sciences Research Ethics Committee (HSS/1092/017H, received on 09 December 2017).

\section{Results}

Several statistical tests were carried out to meet the stated objectives. Reliability analysis was conducted to ascertain the creditability of the results obtained from the study through the consistency of the scales used. The reliability coefficient ranges from 0 to 1 , with 0 indicating the lowest levels of reliability and 1 being the highest indicator. A good indicator 
of reliability is considered to range from 0.7 to 1 (Bujang et al. 2018). The Cronbach Alpha analysis was conducted to evaluate the reliability of the scales; given below are the Cronbach Alpha coefficients (Table 2) for the following constructs under investigation: PU, PEU, SN, FCs, ATU and BIU.

The result of Cronbach Alpha analysis for all the constructs under investigation reveals excellent reliability for all the constructs. The results are indicative of a high degree of consistency amongst the constructs. It also indicates the reliability of the instrument used in this study to collect data.

\section{Demographics}

The questionnaires were distributed amongst 132 lecturers, and the response rate was $100 \%$. Out of the 132 lecturers, $89(67.4 \%)$ were males, representing a high response rate than for females. About 83 (62.9\%) of these lecturers had $\mathrm{PhD}$ as their level of education. About 43 $(32.6 \%)$ had over 15 years of experience. Fifty- three (40.2\%) had 3-6 years of teaching experience using e-learning. Sixty (45.5\%) were from Agriculture, Engineering and Science (Table 3).

\begin{tabular}{lcccl}
\hline TABLE 2: Reliability analysis. & & & \\
Construct & $\begin{array}{c}\text { Cronbach's } \\
\text { alpha }\end{array}$ & $\begin{array}{c}\text { Cronbach's } \\
\text { alpha based on } \\
\text { standardised } \\
\text { items }\end{array}$ & $\begin{array}{c}\text { Number of } \\
\text { items }\end{array}$ & Measure status \\
\hline PU & 0.868 & 0.873 & 4 & Good \\
PEU & 0.926 & 0.929 & 5 & Good \\
SN & 0.904 & 0.904 & 2 & Good \\
FC & 0.850 & 0.847 & 3 & Good \\
ATU & 0.848 & 0.853 & 3 & Good \\
BIU & 0.848 & 0.853 & 3 & Good \\
Tested together & 0.927 & 0.932 & 20 & Good \\
\hline
\end{tabular}

PU, perceived usefulness; PEU, perceived ease of use; SN, subjective norms; FC, facilitating condition; ATU, attitude towards use; BIU, behavioural Intention to use.

TABLE 3: Demographics of study respondents.

\begin{tabular}{llcc}
\hline Measure sure & Items & Frequency & $\mathbf{\%}$ \\
\hline Gender & Male & 89 & 67.4 \\
& Female & 43 & 32.6 \\
Age & $<35$ & 47 & 35.6 \\
& $35-45$ & 32 & 24.2 \\
& $>45$ & 53 & 40.2 \\
Level of education & Honours & 11 & 8.3 \\
& Masters & 38 & 28.8 \\
& Doctor of Philosophy & 83 & 62.9 \\
Teaching experience & $<5$ & 32 & 24.2 \\
& 5-10 & 39 & 29.5 \\
& $11-15$ & 18 & 13.6 \\
& $>15$ & 43 & 32.6 \\
Teaching experience & $<3$ & 41 & 31.1 \\
\cline { 2 - 3 } in e-learning & $3-6$ & 53 & 40.2 \\
& $7-10$ & 20 & 15.2 \\
& $>10$ & 18 & 13.6 \\
College of affiliation & Law and management & 44 & 33.3 \\
& Humanities & 28 & 45.5 \\
& Agriculture, engineering & 60 & 21.2 \\
& and science & & \\
\hline
\end{tabular}

\section{Structural equation modelling analysis}

Confirmatory factor analysis (CFA) was conducted using a statistical tool called Analysis of Moment Structures (AMOS) on the data collected from the 132 lecturers. Confirmatory factor analysis is a model identification measurement, which analyses the loading up of items (observed variables) on the constructs (latent variables). The maximum likelihood estimate method, which decreases the size of standard errors, was selected to estimate the model's parameters (Byrne 2016). The bootstrap method was also selected as the data collected was not normally distributed; it assumes that the sample and the population distributions have the same shape. These measures being controlled made it possible to analyse the data even if the data are non-parametric.

\section{Correlations between model constructs}

There was a significantly strong positive correlation (Table 4) between PU and ATU $(r=0.84, P<0.01)$. Perceived usefulness had a positive correlation $(r=0.63$, $P<0.01$ ) with BIU (Table 4). Perceived ease of use had a weak though significant positive relationship with FC $(r=0.35, P<0.01)$, ATU $(r=0.74, P<0.01)$ and BIU. Attitude towards use and BIU also had a significant positive relationship $(r=0.61, P<0.01)$.

\section{The directional relationship of the constructs}

For every 1 raw score increase in FC, there was a significant $(P<0.001)$ increase of 0.303 raw score in PEU. Subjective norms and PEU were significant $(P<0.01)$ predictors of PU (Table 4). An increase in a raw score of PEU results in a significant $(P<0.001)$ increase of 0.309 raw score in PU. A raw score increase in PU causes a significant $(P<0.01)$ increase in ATU of 0.772 raw score. For every raw score increase in PEU, there is a significant $(P=0.002)$ increase in ATU of 0.199 raw score. A raw score increase in ATU causes a significant $(P<0.01) 0.612$ raw score increase in BIU (Table 5). The total effect is the same value as shown in Table 5 , indicated as an estimate that also shows the relationship direction. The predictors accounted for just $12.5 \%$ of the variation in PEU. However, the predictors for PU, ATU and BIU accounted for $43.8 \%, 73.8 \%$ and $57.4 \%$ of the variation.

TABLE 4: Correlation matrix for the structural equation modelling analysis.

\begin{tabular}{lcccccc}
\hline Variable & FC & SN & PEU & PU & ATU & BIU \\
\hline FC & 1 & - & - & - & - & - \\
SN & 0.30 & 1 & - & - & - & - \\
PEU & 0.35 & 0.11 & 1 & - & - & - \\
PU & 0.29 & 0.54 & 0.45 & 1 & - & - \\
ATU & 0.30 & 0.42 & 0.57 & 0.84 & 1 & - \\
BIU & 0.25 & 0.36 & 0.42 & 0.63 & 0.74 & 1 \\
\hline PU, perceived usefulness; PEU, perceived ease of use; SN, subjective norms; FC, facilitating
\end{tabular}
conditions; BIU, behavioural intention to use; ATU, attitude towards use. 
TABLE 5: Indicating relationship coefficients.

\begin{tabular}{llllccc}
\hline Construct & $\begin{array}{l}\text { Relationship } \\
\text { direction }\end{array}$ & Predictor & Estimate & $\begin{array}{c}\text { Standard } \\
\text { error }\end{array}$ & CR & $P$ \\
\hline PEU & $\leftarrow$ & FC & 0.303 & 0.078 & 3.89 & $*$ \\
PU & $\leftarrow$ & SN & 0.349 & 0.067 & 5.223 & $*$ \\
PU & $\leftarrow$ & PEU & 0.309 & 0.069 & 4.458 & $*$ \\
ATU & $\leftarrow$ & PU & 0.772 & 0.106 & 7.302 & $*$ \\
ATU & $\leftarrow$ & PEU & 0.199 & 0.065 & 3.069 & 0.002 \\
BIU & $\leftarrow$ & PU & 0.009 & 0.178 & 0.053 & 0.958 \\
BIU & $\leftarrow$ & ATU & 0.612 & 0.171 & 3.579 & $*$ \\
\hline
\end{tabular}

PU, perceived usefulness; PEU, perceived ease of use; BIU, behavioural intention to use ATU, attitude towards use; CR, critical ratio; SN, subjective norms; FC, facilitating condition. $*, p<0.01$.

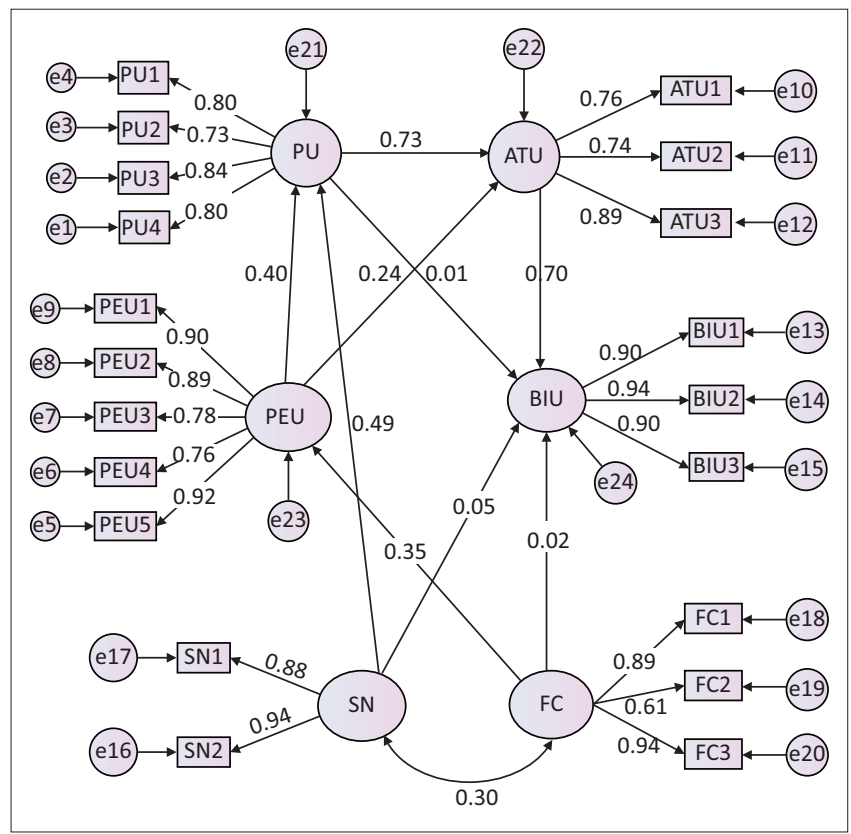

Source: Author's calculation, based on AMOS

PU, perceived usefulness; PEU, perceived ease of use; SN, subjective norms; FC, facilitating condition; ATU, attitude towards use; and BIU, behavioural intention to use.

Model Fit.

FIGURE 5: Results from the structural equation modelling and also for confirmatory factor analysis.

\section{Direct and indirect effects of exogenous variables on the endogenous variable}

Direct effects signify effects of an exogenous variable on the endogenous variable. Facilitating condition had direct effects (predictor) on PEU and BIU indicated by the directional regression line arrow (Figure 5). Facilitating condition and SN are exogenous variables because they are predictors of other variables and are not predicted themselves. Perceived ease of use, PU and ATU are all acting as exogenous and endogenous variables because they are all predictors and also were being predicted. This is indicated by the arrows going out (predictors) and arrows coming in (being predicted). Behavioural Intention to use is endogenous, and it is only being predicted by other variables. All other constructs, directly and indirectly, influence BIU. In Figure 5, PU is a higher significant predictor for ATU with 0.73 using the standardised estimates. One raw score of PU results in a significant 0.73 raw score increase on ATU, contributing to the 0.70 significant effect that ATU has on BIU. Perceived usefulness does not have much direct effect on BIU, but it has more effect through ATU.
TABLE 6: Model fit measures.

\begin{tabular}{lcll}
\hline Measure & Estimate & Threshold & Interpretation \\
\hline CMIN & 346.266 & - & - \\
$\mathrm{df}$ & 159 & - & - \\
$\mathrm{CMIN} / d f$ & 2.178 & Between 1 and 3 & Excellent \\
$\mathrm{CFI}$ & 0.912 & $>0.95$ & Acceptable \\
$\mathrm{TLI}$ & 0.891 & $>0.9$ & Acceptable \\
SRMR & 0.09 & $<0.09$ & Acceptable \\
RMSEA & 0.095 & $<0.06$ & Not acceptable \\
PClose & 0 & $>0.05$ & Not acceptable \\
\hline
\end{tabular}

CMIN, chi-square; $d f$, degrees of freedom; CFI, comparative fit index; TLI, Tucker-Lewis fit index; SRMR, standard root mean square residual; RMSEA, root mean square error of approximation; PClose, $p$-value for testing the null hypothesis of the close fit.

The objective of conducting this analysis was to measure how well the data collected fit the theory under investigation. Table 6 provides the resulting output of the model fit tests against the prescribed threshold. These are the indicators that need to be valid for a model to be deemed fit (Schreiber et al. 2006). These indicators are CMIN which is $\chi^{2}, \mathrm{DF}(\mathrm{df})$ is the degrees of freedom. Owing to the sensitivity of CMIN to sample size, CMIN/DF $\left(\chi^{2} / \mathrm{df}\right)$ is used. Tucker-Lewis fit index (TLI), comparative fit index (CFI), standard root mean square residual (SRMR), root mean square error of approximation (RMSEA) and PClose fit are all analysed. The results revealed that based on the CFI, the model is an acceptable fit to the data, although it is stated that the model does not fit the data well when using RMSEA or PClose (Paulsen \& BrckaLorenz 2018).

\section{Discussion}

The results of the analysis shown in Table 3 in the Results section indicate the response given by respondents when asked to rank their experience with e-learning. From a total of 132 responses on e-learning experience the most frequent response was Moderate $56(42.4 \%)$. It is also indicated that the majority of lecturers still needed assistance in adopting e-learning platforms, even though there were a large number of $\mathrm{PhD}$ holders. Once timely assistance is given, it will make the environment conducive for the adoption process to take place.

The findings of this study showed that there was a correlation with the constructs demonstrating the existence of associations; a change in one would result in a change in the other. All constructs had a significantly positive relationship. The relationship amongst these constructs are supported by the literature (Ajzen 1991; Davis 1989; Venkatesh et al. 2003). A raw score increase in FC was estimated to result in a 0.303 raw score increase in PEU. Therefore, when a university provides training to lecturers on how to use e-learning platforms, then it can expect a significant positive change of $30.3 \%$ in the manner in which lecturers perceive the ease of using that technology as they have a better understanding of it (Rosaline \& Wesley 2017). Both SNs and PEU showed an influence on PU. Perceived usefulness showed a strong influence on ATU with a raw score increase of 0.772 . It is, therefore, crucial for lecturers to 
have a positive perception of the usefulness of e-learning platforms towards their academic work as this will, in turn, increase their attitude towards the use of the technology (Xhaferi \& Bahiti 2018).

The influence on behavioural intention to adopt e-learning was predicted directly and indirectly by the other fiveconstructs. The construct PEU has an indirect influence on behavioural intention by lecturers to adopt e-learning thereby being an indirect predictor.

The fact that a lecturer can perceive e-learning to be easy to use does not mean that they intend to use it in the future, and hence, this construct on its own does not have a direct influence on BIU e-learning. Behavioural intention to use e-learning makes use of a mediator construct, PU. An inference that can be drawn from this is that lecturers not only require to have a perception that e-learning is easy to adopt but also require to find the technology to be useful in performing their duties. The PU, SNs and FCs also indirectly influence BIU e-learning and, at the same time, act as direct predictors of BIU the technology. This is consistent with the literature (Renda dos Santos \& Okazaki 2016; Venkatesh et al. 2003), although according to Teo the construct SNs were found not to be directly influencing behaviour. Figure 5 shows that ATU has a highly significant influence on BIU e-learning.

In terms of model fit, four out of six fit indices accepted the fitness of the model (CMIN/DF, CFI, TLI and SRMR); however, RMSEA and PClose showed a poor fit to the data. It is important to note that the RMSEA fit measurement, although popular, is sensitive to sample sizes lower than 200 cases, given that the sample size used in this study was 132. Despite not producing a perfect fit, it can be argued that the model is a reasonable fit based on the chi-square result as can be justified for models with cases between 75 and 200 (Kenny 2015).

\section{Conclusion}

The challenges in which the world finds itself, such as the COVID-19 disease outbreak and the fast-paced advancement in technology, leading us at the cusp of the fourth industrial revolution (4IR) motivate this study. The study sought to investigate factors that influence behavioural intention to adopt e-learning by lecturers in order to test whether Teo's model applies to the South African context. The findings presented revealed that lecturers' behavioural intention towards the adoption of e-learning is positively influenced by the way they perceive the technology to be useful in their duties, the technologies ease of use, the SNs, the FCs and the lecturer's attitudes towards its use. The findings also revealed that the lecturers' attitude towards the use of e-learning has the most influence towards their BIU e-learning.

The study also showed that Teo's model provides a reasonable fit to the data to understand the adoption of e-learning by lecturers in South African universities. Much as this study's model showed a reasonable fit to the data, it can be recommended that further studies on e-learning adoption model fit be conducted taking into consideration larger sample sizes to get a better understanding of lecturers' adoption of e-learning in South African universities and in a developmental nation context.

\section{Acknowledgement Competing interests}

The author has declared that no competing interest exists.

\section{Author's contributions}

J.N.J. is the sole author of this research article.

\section{Funding information}

The research received no specific grant from any funding agency in the public, commercial or not-for-profit sectors.

\section{Data availability statement}

The datasets generated during the current study are not publicly available because of this being a subset of a broader study, which is currently being completed but are available from the corresponding author on reasonable request.

\section{Disclaimer}

The views and opinions expressed in this article are those of the authors and do not necessarily reflect the official policy or position of any affiliated agency of the authors

\section{References}

Ajzen, I., 1991, 'The theory of planned behavior', Organizational Behaviour and Human Decision Processes 50(2), 179-211. https://doi.org/10.1016/0749-5978 (91)90020-T

Al-Azawei, A., Parslow, P. \& Lundqvist, K., 2016, 'Barriers and opportunities of e-learning implementation in Iraq: A case of public universities', The Internationa Review of Research in Open and Distributed Learning 17(5), 126-146. https://doi. org/10.19173/irrodl.v17i5.2501

Algahtani, A.F., 2011, 'Evaluating the effectiveness of the e-learning experience in some Universities in Saudi Arabia from male students' perceptions', Durham theses, Durham University, Durham.

Al-Samarraie, H., Teng, B.K., Alzahrani, A.I. \& Alalwan, N., 2018, ‘E-learning continuance satisfaction in higher education: A unified perspective from instructors and students', Studies in Higher Education 43(11), 2003-2019. https:// doi.org/10.1080/03075079.2017.1298088

Ansong, E., Boateng, S.L., Boateng, R. \& Effah, J., 2016, 'Determinants of e-learning adoption in Universities: Evidence from a developing country', paper presented at the 2016 49th Hawaii International Conference on System Sciences (HICSS), Koloa, January 05-08, 2016.

Azhar, S., Kim, J. \& Salman, A., 2018, 'Implementing virtual reality and mixed reality technologies in construction education: Students' perceptions and lessons learned', paper presented at the 11th annual International Conference of Education, Seville, Spain, November 12-14, 2018.

Baltodano, M. \& Gomez-Zermeno, M.G., 2017, 'Pedagogical, curricular and didactic elements involved in the creation of an e-learning environment: The case of a Costa Rican University', Turkish Online Journal of Distance Education 18(4), 104-119. https://doi.org/10.17718/tojde.340396

Bujang, M.A., Omar, E.D. \& Baharum, N.A., 2018, 'A review on sample size determination for Cronbach's alpha test: A simple guide for researchers', The Malaysian Journal of Medical Sciences 25(6), 85. https://doi.org/10.21315/mjms2018.25.6.9

Burgess, E.O., 2017, Attrition and dropouts in the e-learning environment: Improving student success and retention, Northcentral University, San Diego, CA.

Byrne, B.M., 2016, Structural equation modeling with AMOS: Basic concepts, applications, and programming, Routledge, New York, NY. 
Chang, C.-T., Hajiyev, J. \& Su, C.-R., 2017, 'Examining the students' behavioral intention to use e-learning in Azerbaijan? The general extended technology acceptance model for e-learning approach', Computers \& Education 111, 128-143. https:// model for e-learning approach', Computers
doi.org/10.1016/j.compedu.2017.04.010

Davey, B., Elliott, K. \& Bora, M., 2019, 'Negotiating pedagogical challenges in the shift from face-to-face to fully online learning: A case study of collaborative design solutions by learning designers and subject matter experts', Journal of University Teaching and Learning Practice 16(1), 3.

Davis, F.D., 1989, 'Perceived usefulness, perceived ease of use, and user acceptance of information technology', MIS Quarterly 13(3), 319-340. https://doi.org/ $10.2307 / 249008$

DHET, 2020, South African public universities, viewed 13 January 2020, from http:// www.dhet.gov.za.

Dwivedi, Y.K., Rana, N.P., Jeyaraj, A., Clement, M. \& Williams, M.D., 2019, 'Re-examining the unified theory of acceptance and use of technology (UTAUT): Towards revised theoretical model', Information Systems Frontiers 21(3), 719-734. https:// doi.org/10.1007/s10796-017-9774-y

El-Masri, M. \& Tarhini, A., 2017, 'Factors affecting the adoption of e-learning systems in Qatar and USA: Extending the Unified Theory of Acceptance and Use of Technology 2 (UTAUT2)', Educational Technology Research and Development 65(3), 743-763. https://doi.org/10.1007/s11423-016-9508-8

Flavin, M. \& Quintero, V., 2018, 'UK higher education institutions' technologyenhanced learning strategies from the perspective of disruptive innovation Research in Learning Technology 26, 1987. https://doi.org/10.25304/rlt.v26.1987

Flaxman, S., Mishra, S., Gandy, A., Unwin, H., Coupland, H., Mellan, T. et al., 2020, Report 13: Estimating the number of infections and the impact of non-pharmaceutical interventions on COVID-19 in 11 European countries, Imperial College, London.

Freeman, E., Antwi-Boampong, A. \& Agyemang, O.B.-K., 2019, 'Students' learning experience within a blended learning environment in a higher education institution in Ghana', paper presented at the Ecel19-Proceedings of the 18th European Conference on E-learning, Copenhagen, November 07-08, 2019.

Güllü, F., Kuusik, R., Shogenov, K., Laanpere, M., Oysal, Y., Sözcü, Ö.F. et al., 2016, 'An analysis and comparison of adoption of e-learning systems in higher education by lecturers at largest universities in Estonia and Turkey', Baltic Journal of Modern Computing $4(3), 428$.

Hale, T., Petherick, A., Phillips, T. \& Webster, S., 2020, Variation in government responses to COVID-19, Blavatnik School of Government Working Paper, 31 Blavatnik School of Government, Oxford.

Ingadottir, B., Thylén, I., Ulin, K. \& Jaarsma, T., 2020, 'Patients are expecting to learn more: A longitudinal study of patients with heart failure undergoing device implantation', Patient Education and Counseling 103, 1382-1389.

Kenny, D., 2014, Measuring model fit in structural equation modeling, viewed n.d., from http://davidakenny.net/cm/fit.htm

Kristanto, A., 2017, 'The development of instructional materials e-learning based on blended learning', International Education Studies 10(7), 10-17. https://doi. org/10.5539/ies.v10n7p10

Mertler, C.A. \& Reinhart, R.V., 2016, Advanced and multivariate statistical methods: Practical application and interpretation, Taylor \& Francis, Los Angeles, CA

Mládková, L., 2017, 'Learning habits of generation Z students', paper presented at the European Conference on Knowledge Management, Barcelona, Spain, September 07-08, 2017.

Moakofhi, M., Leteane, O., Phiri, T., Pholele, T. \& Sebalatlheng, P., 2017, 'Challenges of introducing e-learning at Botswana University of agriculture and natura resources: Lecturers' perspective', International Journal of Education and Development Using ICT 13(2), 4-20.

Molina-Castillo, F.-J., Lopez-Nicolas, C. \& De Reuver, M., 2020, 'Mobile payment: The hiding impact of learning costs on user intentions', Journal of Theoretical and Applied Electronic Commerce Research 15(1), 1-12. https://doi.org/10.4067/ S0718-18762020000100102

Morin, D., Fard, H.S. \& Saadé, R.G., 2019, 'Understanding online learning based on different age categories', Issues in Informing Science and Information Technology 16, 307-317. https://doi.org/10.28945/4313

Mosa, A.A., Mahrin, M.N.b. \& Ibrrahim, R., 2016, 'Technological aspects of e-learning readiness in higher education: A review of the literature', Computer and Information Science 9(1), 113-127. https://doi.org/10.5539/cis.v9n1p113

Nikou, S.A. \& Economides, A.A., 2017, 'Mobile-based assessment: Investigating the factors that influence behavioral intention to use', Computers \& Education 109 56-73. https://doi.org/10.1016/j.compedu.2017.02.005

Nzimande, 2020, The minister of higher education, science and innovation: Statement on measures to deal with the Covid-19 threat in the post-school education and training sector [Press release], viewed 20 March 2020, from http://www.dhet.gov. za/SiteAssets/Media\%20Statement $\% 202020$ /DHET\%20COVID-19\%20 za/SiteAssets/Media\%20Statement\%202020/DHE

Opoku, D., Pobee, F. \& Okyireh, R.O., 2020, 'Determinants of e-learning system adoption among ghanaian university lecturers: An application of information system success and technology acceptance models', Humanities 5(1), 151-168. https://doi.org/10.20448/801.51.151.168

Oteng-Peprah, M., De Vries, N. \& Acheampong, M., 2020, 'Households' willingness to adopt greywater treatment technologies in a developing country - Exploring a modified theory of planned behaviour (TPB) model including personal norm',
Journal of Environmental Management 254, 109807. https://doi.org/10.1016/j. jenvman.2019.109807
Parent24, 2017, South Africa's universities and colleges: Contact details, viewed 16 January 2020, from http://www.parent24.com/Learn/Tertiary-education/ south-africas-universities-and-colleges-contact-details-20160316.

Patel, N.M., Kadyamatimba, A. \& Madzvamuse, S., 2018, 'E-learning adoption in ruralbased higher education institutions in South Africa', paper presented at the 2018 Open Innovations Conference (OI), Johannesburg, October 03-05, 2018.

Pattanayak, S., Mohapatra, S., Mohanty, S. \& Choudhury, T., 2019, 'Empowering of CT-based education system using cloud computing', in H.S. Saini, R. Sayai, A. Govardhan \& R. Buyya (eds.), Innovations in computer science and engineering, pp. 113-120, Springer, Singapore.

Paulsen, J. \& BrckaLorenz, A., 2018, Construct validity: 2017 scales, viewed 02 September 2019, from https://nsse.indiana.edu/fsse/

Priya, K., Elayampalayam, T. \& Nadu, T., 2018, 'Information and communication technology as change agent for education sector for women in India', Internationa Journal of Pure and Applied Mathematics 120(6), 323-333.

Renda dos Santos, L.M. \& Okazaki, S., 2016, 'Planned e-learning adoption and occupational socialisation in Brazilian higher education', Studies in Higher Education 41(11), 1974-1994. https://doi.org/10.1080/03075079.2015 1007940

Rogers, E.M. (ed.), 2010, Diffusion of innovations, Simon and Schuster, New York, NY.

Rosaline, S. \& Wesley, J.R., 2017, 'Factors affecting students' adoption of ICT tools in higher education institutions: An Indian context', International Journal of Information and Communication Technology Education (IIICTE) 13(2), 82-94. https://doi.org/10.4018/IJICTE.2017040107

Savari, M. \& Gharechaee, H., 2020, 'Utilizing the theory of planned behavior to predict Iranian farmers' intention for safe use of chemical fertilizers', Journal of Cleaner Production 263, 121512. https://doi.org/10.1016/j.jclepro.2020.121512

Schmidthuber, L., Maresch, D. \& Ginner, M., 2020, 'Disruptive technologies and abundance in the service sector-toward a refined technology acceptance model', Technological Forecasting and Social Change 155, 119328. https://doi. org/10.1016/j.techfore.2018.06.017

Schreiber, J.B., Nora, A., Stage, F.K., Barlow, E.A. \& King, J., 2006, 'Reporting structural equation modeling and confirmatory factor analysis results: A review', The Journal of Educational Research 99(6), 323-338. https://doi.org/10.3200/ JOER.99.6.323-338

Singh, C.S., 2017, 'Impact of information and communication technology on higher education in India', International Journal of Information Research and Review 4(12), 4912-4916.

Sugandini, D., Purwoko, P., Pambudi, A., Resmi, S., Reniati, R., Muafi, M. et al., 2018 The role of uncertainty, perceived ease of use, and perceived usefulness towards the technology adoption', International Journal of Civil Engineering and Technology 9(4), 660-669.

Sultan, P., Tarafder, T., Pearson, D. \& Henryks, J., 2020, 'Intention-behaviour gap and perceived behavioural control-behaviour gap in theory of planned behaviour: Moderating roles of communication, satisfaction and trust in organic food consumption', Food Quality and Preference 81, 103838. https://doi.org/10.1016/j. foodqual.2019.103838

Tarhini, A., Al-Busaidi, K.A., Mohammed, A.B. \& Maqableh, M., 2017, 'Factors influencing students' adoption of e-learning: A structural equation modelin approach', Journal of International Education in Business 10(2), 164-182. https:// doi.org/10.1108/JIEB-09-2016-0032

Teo, T., 2011, 'Factors influencing teachers' intention to use technology: Mode development and test', Computers \& Education 57(4), 2432-2440. https://doi. org/10.1016/j.compedu.2011.06.008

Teo, T. \& Lee, C.B., 2010, 'Explaining the intention to use technology among student teachers: An application of the Theory of Planned Behavior (TPB)', Campus-Wide Information Systems 27(2), 60-67. https://doi.org/10.1108/10650741011033035

Teo, T. \& Noyes, J., 2014, 'Explaining the intention to use technology among preservice teachers: A multi-group analysis of the unified theory of acceptance and use of technology', Interactive Learning Environments 22(1), 51-66. https://doi.or g/10.1080/10494820.2011.641674

Ting, S.R., Smith, A.C. \& Gomez, E., 2018, 'E-learning in China: Progress, challenges, and research issues', in H. Spires (ed.), Digital transformation and innovation in Chinese education, pp. 1-17, IGI Global, Chapel Hill, NC.

Vaona, A., Banzi, R., Kwag, K.H., Rigon, G., Cereda, D., Pecoraro, V. et al., 2018 'E-learning for health professionals', Cochrane Database of Systematic Reviews (1). https://doi.org/10.1002/14651858.CD011736.pub2

Venkatesh, V., Morris, M., Davis, G. \& Davis, F.D., 2003, 'User acceptance of information technology: Toward a unified view', MIS Quarterly 27(3), 425-478. https://doi. org/10.2307/30036540

Wall, L., Nartker, A., McGee, A., Scott, E. \& Downer, A., 2017, 'No internet? No problem! Creative approaches to cost-effective e-learning delivery in resourceconstrained settings', The Lancet Global Health 5, S8. https://doi.org/10.1016/ constrained settings', The

Xhaferi, G. \& Bahiti, R., 2018, 'Lecturers' attitudes towards integration of e-learning in higher education. Case study: University of Tetovo', International Journal of Computer Science and Information Security 16(5), 240-249. https://doi. org/10.24018/ejece.2018.2.5.26

Zhang, D., Zhao, J.L., Zhou, L. \& Nunamaker, Jr. J.F., 2004, 'Can e-learning replace classroom learning?', Communications of the ACM 47(5), 75-79. https://doi. org/10.1145/986213.986216 